\title{
A CONSTRUÇÃO DA PERSONAGEM SÁDICA NOS ROMANCES: XICA DA SILVA, DE JOÃO FELÍCIO DOS SANTOS E CHICA QUE MANDA, DE AGRIPA VASCONCELOS
}

\section{THE CONSTRUCTION OF THE SADISTIC CHARACTER IN THE NOVELS: XICA DA SILVA, BY JOÃO FELÍCIO DOS SANTOS, AND CHICA QUE MANDA, BY AGRIPA VASCONCELOS}

Renata Aparecida Ferreira Ribas*

Maurício Cesar Menon ${ }^{* *}$

\begin{abstract}
Resumo: A protagonista dos romances Chica que manda (1966), ${ }^{1}$ de Agripa Vasconcelos e Xica da Silva (1976), ${ }^{2}$ de João Felício dos Santos, é baseada na figura emblemática da história brasileira Chica da Silva, ${ }^{3}$ escrava que se tornou "Sinhá" no século XVIII, ao se casar com um dos homens mais poderosos, o contratador de diamantes João Fernandes de Oliveira. Este trabalho evidencia as semelhanças e diferenças na caracterização do sadismo empregada na construção da personagem em cada romance, pois se percebe que os escritores, embora apontem para tal característica, o fazem de maneira diversa.

Palavras-chave: Personagem; Sadismo; Romance Histórico.
\end{abstract}

Abstract: The protagonist of the novels Chica que manda (1966), by Agripa Vasconcelos, and Xica da Silva (1976), by João Felício dos Santos, is based on the emblematic figure of Brazilian history Chica da Silva, a slave who became "Sinhá" in the 18th century by marrying one of the most powerful men, the diamond contractor João Fernandes de Oliveira. The paper demonstrates the similarities and differences in the characterization of sadism employed in the construction of the character in each

\footnotetext{
"Mestranda em Letras pela Universidade Tecnológica Federal do Paraná (UTFPR), câmpus de Pato Branco. E-mail: reeapferreira@hotmail.com.

"* Doutor em Letras pela Universidade Estadual de Londrina (UEL), professor da UTFPR de Campo Mourão. E-mail: mauriciomenon983@gmail.com.

${ }^{1}$ Ano da primeira publicação da obra de Agripa Vasconcelos.

${ }^{2}$ Ano da primeira publicação da obra de João Felício dos Santos.

${ }^{3}$ Embora cada romance aqui estudado traga a grafia do nome da personagem de forma diferente, adotaremos aquela feita pelo escritor Agripa Vasconcelos, ou seja, a iniciada por Ch.
} 
novel, as it is clear that the writers, although they both point to such trait, do it in different ways.

KEYwords: Character; Sadism; Historical Novel.

\section{INTRODUÇão}

O romance histórico tem, como plano de fundo para as ações ficcionais de seus personagens, entre outros elementos, fatos ou pessoas históricas. No caso dos romances de João Felício dos Santos e de Agripa Vasconcelos aqui estudados, a protagonista das obras é inspirada na personagem homônima que figura nos anais da história mineira do século XVIII. Parda e escrava, Chica encantou o contratador de diamantes João Fernandes de Oliveira, que dela fez sua esposa, embora não oficialmente aos olhos da lei, por conta dos impedimentos da época. Chica tornou-se, dessa forma, uma sinhá reconhecida na sociedade mineira do século XVIII, seja pela sua excentricidade, seja por sua condição de poder a que é alçada desde o momento em que passa a viver como esposa do contratador à vista de todos. Como Miranda (2017, p. 280) afirma: "Ao contrário do que sempre pensamos, havia muitas 'Chicas' na região e no período, ela apenas foi a mais paradigmática. Quase todos os homens brancos na área diamantina $\mathrm{e}$ do ouro eram amasiados publicamente com negras".

Este trabalho pretende mostrar como foi feito esse processo de modulação dessa figura histórica em personagem ficcional, destacando alguns aspectos textuais que são utilizados para realçá-la como sádica. Para isso, considerando a importância da relação literatura e história, o trabalho fará, em um primeiro momento, a explanação sobre essa relação, como forma de ressaltar que a história é o plano de inspiração para a construção da narrativa ficcional, não sendo uma obra que busca imitar fatos históricos, mas ir além, no imaginário do cotidiano dos personagens para discuti-los. Dessa maneira, evidenciando a pluralidade de vozes possíveis sobre fatos e pessoas históricas, por meio da ficcionalização, temos contato com interpretações sobre determinado dado historiográfico que, por sua vez, nunca se encontra totalmente fechado, mantendo-se permeável à ficção.

$\mathrm{Na}$ sequência, serão apresentados os romances e seus escritores como forma de apresentar ao leitor os enredos e de que maneira a protagonista é detalhada. Percebe-se, em um primeiro momento, que o fundo de inspiração dos dois é o cenário em que se passou a real história de Chica, pois ambos utilizam dados historiográficos verídicos sobre ela, amalgamando-os a elementos ficcionais para preencher as lacunas, as quais a historiografia não completa.

O elemento primordial da análise será a característica sádica empregada por ambos na protagonista. Primeiramente, salienta-se que as palavras sádico e sadismo possuem, em sua conceituação, dois direcionamentos. Um usado para descrever pessoas que sentem prazer com a dor alheia, e outro usado para descrever o sentimento de prazer erótico sentido ao se 
praticar atos cruéis. Os escritores trabalham cada um desses direcionamentos pelo viés da conceituação, porém ambos constroem suas protagonistas como sádicas em algumas das ações que lhes cabem. Enfim, por meio de teorias de construção de personagem, será apontado como os escritores se valeram de artifícios narrativos para alcançarem a credibilidade dos leitores com suas construções ficcionais. Esta parte se liga intimamente à anterior, uma vez que procura apontar aspectos de linguagem e da narrativa que compõem as protagonistas dentro de um recorte específico, o que sugere uma verossimilhança interna dos textos a que os autores se mantiveram fiéis.

\section{O GÊNERO LITERÁRIO: O ROMANCE HISTÓRICO}

Segundo Mikhail Bakhtin (1990, p. 110), o romance é um gênero híbrido. Híbrido porque nele duas vozes caminham juntas e lutam no território do discurso. Dois pontos de vista que não se misturam, mas se cruzam dialogicamente. Essa construção híbrida tem uma importância capital para o romance, uma vez que "pertence a um único falante, mas onde, na realidade, estão confundidos dois enunciados, dois modos de falar, dois estilos, duas "linguagens", duas perspectivas semânticas e axiológicas” (ESTEVES, 2010, p. 19).

Assim, o romance é um espaço de criação, ao mesmo tempo que busca representar algo do mundo real de um determinado ponto de vista, configurado dentro de um recorte temporal ou espacial de maior ou menor abrangência. Logo, reforça-se que o romance histórico se trata de um gênero híbrido composto pela relação entre história e ficção. Por mais que ele sustente, porém, personagens e/ou fatos históricos, ressalta-se que se trata de uma ficção e não de uma transcrição do real.

No romance histórico, portanto, não se trata do relatar contínuo dos grandes acontecimentos históricos, mas do despertar ficcional dos homens que os protagonizaram. Trata-se de figurar de modo vivo as motivações sociais e humanas a partir das quais os homens pensaram, sentiram e agiram de maneira precisa, retratando como isso ocorreu na realidade histórica (LUKÁCS, 2011, p. 60).

Como Lukács (2011) afirma, essa modalidade de narrativa tem como objetivo nos apresentar como os indivíduos de determinado período agiam, pensavam ou sentiam, assim podemos ter um conhecimento da constituição social daquela época. Ou seja, no caso dos romances trabalhados por esta análise, teríamos um contato com indivíduos e fatos do período colonial brasileiro, demarcados em seus aspectos sociais, culturais e políticos. O romance histórico aponta, muitas vezes, para a existência de diferentes visões dos eventos históricos registrados, 
tornando possível uma pluralidade de versões e interpretações desses acontecimentos. Assim, desmistifica-se que o objetivo desse gênero seria representar a realidade histórica pelo viés da imitação, como Weinhardt (1994) ressalta:

[...] Ao romance histórico não interessa repetir o relato dos grandes acontecimentos, mas ressuscitar poeticamente os seres humanos que viveram essa experiência. Ele deve fazer com que o leitor apreenda as razões sociais e humanas que fizeram com que os homens daquele tempo e daquele espaço pensassem, sentissem e agissem da forma como o fizeram. Trata-se de uma norma da figuração literária, aparentemente paradoxal, que se alcance esta apreensão focalizando os detalhes do quotidiano que parecem insignificantes. Os grandes dramas e as figuras históricas centrais são próprios para a epopéia. O mundo do romance é o da esfera popular. Esta, tensionada pela revolução, pode revelar suas forças, surgindo naturalmente os heróis que para a história são incógnitos (WEINHARDT, 1994, p. 51).

Essas particularidades da narrativa por Weinhardt (1994) citadas são observáveis nas obras de João Felício dos Santos e de Agripa Vasconcelos, pois o enfoque histórico está na vida cotidiana das personagens, que expressam seu modo de vestir, de se comportar, de pensar e de sentir, coerentes com o século XVIII. Quando se trata da personagem principal Xica da Silva, a narrativa apresenta o seu dia-a-dia como esposa do contratador e como a sociedade a trata e a vê ocupando o lugar que se julga pertencer a uma mulher branca, pelo pensamento do período colonial.

A partir dessa constatação, observamos de que maneira a personagem quebra um grande paradigma social, cultural e político da época, mostrando que sua cor não a torna impossibilitada de ocupar essa posição social que lhe é outorgada.

O romance histórico tem, como objetivo, interpretar dados históricos, tentando solucionar questionamentos em que a história não foi capaz de redigir, por falta de material documental. Sendo assim, Esteves (2010) ressalta:

Não se trata, entretanto, de substituir a história pela ficção, mas de possibilitar uma aproximação poética em que todos os pontos de vista, contraditórios mas convergentes, estejam presentes, formando o que Steenmeijer (1991, p. 25) chama de representação totalizadora. Segundo este último ponto de vista, e usamos aqui a feliz expressão de Heloísa Costa Milton (1992), a literatura pode ser considerada uma leitora privilegiada dos signos da história (ESTEVES, 2010, p. 13).

O escritor enfatiza que esse tipo de obra não busca ficcionalizar totalmente os fatos históricos, mas apontar possíveis leituras interpretativas deles por meio da ficção. Considerando 
que pessoas de esferas sociais podem possuir interpretações diferentes para um mesmo fato, é evidente que se diferenciarão em seus argumentos e descrições. Portanto, o que a literatura se propõe a fazer é apresentar uma leitura sobre signos históricos de um determinado fato escolhido, ou seja, no caso de Chica da Silva, entender como o Contratador João Fernandes de Oliveira se interessa justamente por ela, e não por uma mulher branca, preferência para os padrões da época.

O esquema do romance histórico criado por Scott, que acabou por se impor como modelo, obedece a dois princípios. O primeiro deles é que a ação ocorre em um passado anterior ao presente do escritor, tendo como pano de fundo um ambiente rigorosamente reconstruído, onde figuras históricas ajudam a fixar a época. Sobre esse pano de fundo situa-se uma trama fictícia, com personagens e fatos inventados pelo autor. Além disso, como segundo princípio, os romances de Scott e seus seguidores, bem ao gosto romântico, costumam introduzir na trama ficcional um episódio amoroso geralmente problemático, cujo desenlace pode variar, ainda que, na maioria das vezes, termine na esfera do trágico (ESTEVES, 2010, p. 19).

Os princípios citados configuram o romance histórico tradicional e são observáveis nas obras utilizadas. Os escritores retratam o século XVIII, nas Minas Gerais, porém escrevem em uma época posterior ao desenlace do enredo, Vasconcelos em 1966 e Santos em 1976. Em partes, também percebemos o segundo princípio, o gosto romântico presente nas obras, muitas vezes entremeado de lances de caráter naturalista, como se vê em Agripa Vasconcelos. Ambas as obras trabalham com a problemática amorosa, envolvendo o relacionamento de Chica da Silva com o contratador de diamantes João Fernandes de Oliveira, e terminam de forma trágica, com o casal sofrendo uma separação imposta a eles com a prisão do contratador em Portugal.

Assim, o romance histórico aponta, muitas vezes, a existência de diferentes visões dos eventos históricos registrados, tornando possível uma multiplicidade de possibilidades de versões e interpretações desses acontecimentos. O escritor do romance histórico procura evocar acontecimentos sociais de uma determinada época, e que, de alguma forma, possua impacto na sociedade atual do qual faz parte. Ele apresenta fatos vividos da história, recriando impressões pessoais e coletivas sobre os eventos ocorridos.

Pois assim se concretiza a memória, lembranças individuais são partilhadas e recebem uma forma material, seja na fala ou na escrita, seja por meio de imagens, objetos guardados, ruínas, monumentos... E quanto maior visibilidade e aceitação (ou imposição) social essas lembranças têm, mais elas integram a memória "oficial" de uma sociedade (SOETHE, 2009, p. 161). 
Desse modo, a literatura faz uso do discurso como mecanismo consciente de fixação da memória. "E como interessa aos textos literários figurar as dinâmicas do discurso, as obras procuram abrigar a pluralidade de vozes, incluindo os diversos pontos de vista que contribuem para fixar os conteúdos da memória" (SOETHE, 2009, p. 161). Ou seja, quando o texto trabalha, como, por exemplo, com a imagem de uma pessoa ou fato histórico, seus personagens apresentam cada qual seu ponto de vista sobre o assunto, como forma de reforçar a presença e o impacto causado pelo objeto histórico na sociedade. Assim, não apenas o discurso literário, mas também o discurso histórico passam a refletir sobre a existência da pluralidade de vozes sobre algo histórico.

\section{OS ROMANCES E SEU CONTEXTO HISTÓRICO}

Os enredos dos romances aqui analisados se passam no século XVIII, na Comarca do Serro Frio, em Minas Gerais, em uma sociedade colonial, onde os negros eram escravizados e a mineração movimentava a colônia. Segundo as palavras de Joel Rufino dos Santos (2007), as quais acompanham a contracapa da terceira edição do romance Xica da Silva em questão,

a sociedade mineradora foi a primeira a se parecer com o Brasil de hoje. Célere, vibrátil, multirracial, espetacular. Ali nasceram a vida urbana, a política, o espírito de autonomia, a classe média, o roubo do dinheiro público, a burocracia, a desigualdade brutal, a favela (sob nome de quilombo), o domínio estrangeiro, as estradas, os bancos, a festa, o baile, o namoro, a música, a literatura, o mercado interno e o contrabando. Diante das Minas, o mundo do açúcar, mais antigo, parecia pré-histórico" (SANTOS, 2007, n.p.).

Vasconcelos era mineiro, iniciou sua carreira literária com o livro Silêncio (1920), que o levou, aos 22 anos de idade, a conquistar um lugar na Academia Mineira de Letras, sucedendo a Alphonsus de Guimaraens. Em 1949, obteve o prêmio Olavo Bilac da Academia Brasileira de Letras. Atuou como médico e escritor, tendo evidente interesse por assuntos de natureza variada, todavia a literatura é que se torna o epicentro da propagação de suas ideias. Publicou alguns ensaios e textos de caráter científico na área da saúde, mas dedicou-se mesmo a produzir poesias, prosas e romances.

E não sem razão. Sua obra, múltipla e vasta, revela o domínio da narrativa, a paixão pela matéria viva e o real, a inteligência lírica que a fazem detentora de beleza universal. Através de cuidadosa pesquisa com as palavras, que vai buscar nos falares antigos, nos dialetos africanos, nas prosas mineiras, Agripa revela um tesouro escondido de sons, cores e emoções que ele nos convida a descobrir (MANCINI; MENON; SILVA, 2018, n.p.). 
Na narrativa de Vasconcelos (2010), a personagem Chica da Silva é escrava do Sargentomor. Descrita como pessoa tímida, ela encanta o contratador João Fernandes de Oliveira, que a compra e a torna sua esposa. Quando ela passa de escrava a esposa, começa a se comportar como uma verdadeira senhora branca, como forma de ser aceita e respeitada pela sociedade colonial. Ademais, como é típico dos senhores, praticará também alguns atos de crueldade contra escravos e escravas, toda vez que se sente ameaçada em relação ao seu casamento com o contratador.

No decorrer da narrativa, a protagonista comete inúmeros atos cruéis, ou seja, atos sádicos, pois proporcionavam-lhe prazer e contentamento. Chama cada vez mais a atenção das demais pessoas da sociedade, incomodando principalmente seus inimigos, que a invejavam pelo posto social que ela ocupava. Disso resultam inúmeras denúncias à corte, devido ao estilo exuberante de vida do casal, que fazem João Fernandes ser intimado e, posteriormente, preso. Ao fim, a protagonista acaba sozinha e atormentada por suas atitudes cruéis que cometera no passado.

O romance Xica da Silva foi escrito por João Felício dos Santos e teve sua primeira publicação em 1976. Este foi escritor, jornalista e roteirista, com uma vasta quantidade de obras, entre elas: Ganga Zumba (1962), livro premiado pela Academia Brasileira de Letras; Carlota Joaquina (1968); e Margueira Amarga (1985). Destaca-se que foi um dos representantes da ficção histórica, ou seja, do romance baseado em fatos reais. "Sempre procurou abordar a história dos esquecidos, daqueles que foram excluídos à força pelos vencedores” (DIEGUES, 2007, on-line). Diegues (2007) ainda reforça que o escritor haveria escrito primeiramente o roteiro do filme e, somente após sua conclusão, o livro. Afirma que "[...] é um caso raro de um filme que deu origem a um livro" (DIEGUES, 2007, on-line).

A narrativa se inicia com Chica sendo escrava do Sargento-mor; descrita com muito erotismo, manterá relações sexuais com o seu senhor e com o filho dele. Em uma visita ao dono de Chica, o intendente Mucó se sente atraído por ela e tem interesse em comprá-la, porém seu pedido é negado. Todavia, com a chegada do contratador de diamantes João Fernandes de Oliveira, a escrava sente-se atraída pelo rapaz e deseja que ele seja seu próximo dono, como observamos em sua conversa com Zezé: “-Ele é formoso, Zezé! Ele é diferente do mundo! Até parece um príncipe, uai!” (SANTOS, 2007, p. 35). O seu sentimento pelo contratador a faz cometer atitudes em busca da atenção dele, que logo se sentirá atraído por ela e acabará por comprá-la, tornando-a sua esposa. As cenas dos encontros sexuais entre eles são bem descritas, evidenciando que Chica tinha um dom ou conhecimento sobre isso - "-Ufa! Xiquinha, meu Deus! Meu amor... Você me acaba, menina sabida! Assim, nem na França, acredite...” (SANTOS, 2007, p. 80) -, e tendência ao sadomasoquismo - "João Fernandes é que, não obstante o costumeiro exercício em cruentos diários, berrava, se defendendo com unhas e dentes, das carícias infernais da mulata que, repetidas ao infinito, sem vão de tréguas, se faziam um cristão chegar aos paroxismos do céu, atiravam-no, também e ao mesmo tempo, aos piores 
suplícios infernais" (SANTOS, 2007, p. 109). Ela conquista sua carta de alforria e, de escrava, torna-se esposa de João Fernandes de Oliveira. O contratador, rendido de amores a Chica, procura realizar todos os desejos dela, por mais hiperbólicos que fossem, como construir um lago e um navio para realizar o seu sonho de conhecer o mar.

Isso tudo causa inveja e revolta nas pessoas da burguesia, o que faz chegarem cartas de denúncias ao Marques de Pombal e até mesmo ao rei. Sendo assim, o Conde Valadares é enviado para cumprir um mandado de prisão ao contratador João Fernandes de Oliveira. Porém, o mandado levou sete meses para ser realizado, e, com a prisão de seu amado, Chica ficou desprotegida e foi humilhada pelo povo. Sem direção para onde ir, procura um de seus antigos parceiros, Zezé, com que achará consolo.

\section{A CONSTRUÇÃo DA PERSONAGEM CHICA DA SILVA}

Primeiramente, a análise partirá do conceito das palavras sádico e sadismo, pois elas serão usadas nesta etapa, fazendo-se necessário entendermos seus significados. Assim, como forma de entender como cada escritor empregou a característica sádica na construção de suas personagens, vejamos a conceituação de sádico e sadismo apresentada pelo dicionário Aurélio (FERREIRA, 2010, p. 619, grifo nosso):

Sádico [Do fr. Sadique]

Adjetivo

1. Relativo a, ou em que há sadismo, ou próprio dele: assuntos sádicos; pendores sádicos; literatura sádica.

2. Que é dado à prática do sadismo.

3. P. ext. Que se deleita em fazer sofrer a outrem; mau, cruel, tirano.

Sadismo [Do fr. Sadisme.]

Substantivo masculino

1. Psiq. Parafilia em que a satisfação erótica advém de atos de violência ou crueldade física ou moral infligidos ao parceiro sexual; algolagnia ativa.

2. P. ext. Prazer com o sofrimento alheio.

Podemos observar, com a citação anterior, que os termos sádico e sadismo possuem duas conceituações para interpretações, a primeira que caracteriza uma pessoa que comete atos cruentos que resultam em sua satisfação espiritual, e outra que caracteriza a pessoa que, no ato sexual, comete ações que provoquem dor em seu parceiro, como forma de obter prazer sexual em si mesma. No caso das personagens protagonistas dos romances Chica que manda e Xica da Silva, notamos que cada uma segue um dos percursos da significação dos termos.

A primeira a se observar é a personagem Chica, de Agripa Vasconcelos, caracterizada como sádica pelo viés de cometer atos de crueldade por motivações fúteis, mas que a satisfazem 
interiormente e reverberam sobre seu humor. Uma das passagens da narrativa que expressa fortemente o lado sádico de Chica é a morte de Graça, encomendada por ela, pois achava que João Fernandes de Oliveira tinha atração pela ladina; mandou, então, que a enterrassem viva, deixando apenas a cabeça descoberta. Após algumas horas do ato cometido, "às dez da noite, Chica mandou ver como iam as coisas. Sentia um desafogo confortador, um bem-estar, uma paz de água represada que serena depois do estrondo da cachoeira" (VASCONCELOS, 2010, p. 209). Percebemos que ela estava se sentindo satisfeita com a morte da ladina. No dia seguinte, ela vai conferir a encomenda:

Chica foi ver a enterrada viva. As pálpebras violáceas estavam meio caídas e a boca entreaberta em espasmo final, deixando ver alguns dentes muito brancos. Os cabelos que outrora viviam floridos de sempre vivas estavam acamados no chão, sujos de terra.

Em torno, as árvores molhadas gotejavam restos de água caída até a alva do dia. Nos lábios e nas pálpebras do cadáver formigas roíam a pele empalidecida.

Cabeça fora com ela. Recebeu ordens:

Diga a Jaconias que traga um enxadão.

Arrancou uma folha e começou a morde-la, calada. Ficou escutando. Não havia pássaros na manhã úmida. As árvores molhadas continuavam a gotejar no chão lamacento.

Jaconias, arranque essa cabeça com o enxadão.

Com quatro golpes curtos e duros, como quem desenterra um toco, o preto arrancou a cabeça.

Agora cave ai mesmo um buraco e enterre isso (VASCONCELOS, 2010, p. 209).

Observando o trecho transcrito da visita para conferir as ordens dadas em relação à execução de Graça, notamos como a morte encomendada possuía traços de pura crueldade, pois a ladina fora torturada, a ter seu corpo enterrado enquanto estava viva, e ali ter que esperar sua morte que era certa. Ao se deparar com a cena, Chica não se mostra abalada nem arrependida, ainda continua seu castigo com o corpo desfalecido, mandando-lhe arrancar a cabeça e fazendo questão de assistir ao ato. Esses são traços evidentes de que Chica era sádica nesta representação literária da personagem.

Seu sadismo é reforçado quando João Fernandes de Oliveira compra uma bela ladina, Anselma, e elogia os seus dentes. Chica, enciumada, ordena arrancar todos e, posteriormente, manda a ladina apresentar-se com uma salva para o homem; "estavam na salva todos os dentes da própria Anselma, arrancados a torquês" (VASCONCELOS, 2010, p. 148). Após o ato, "havia paz na sua fisionomia descansada, apenas com as olheiras mais profundas. Leonor, que não vira Chica desde a antevéspera, não reconhecia ali a fera que mandou arrancar os dentes da mucana" (VASCONCELOS, 2010, p. 150). 
Outra atitude de Chica que evidencia seu sadismo por ciúmes é quando ela, frustrada, supõe que o filho de um dos escravos não era dele, pois possuía tom de pele mais claro que o dos pais. Para ela, o bebê poderia ser de João Fernandes de Oliveira. Sendo assim, assombrada por seus ciúmes, faz uma visita à casa do recém-nascido:

Pegou-o com jeito e saiu calma à beira do rio, com ele nos braços. Quando a mãe viu, não teve susto. Sorria agradecida da lembrança da patroa de pegar seu filho.

Chegando na barranca da pedra do poção fundo, ela desenrolou as baetas do corpo do pequerrucho e, num gesto repentino, em assomo alucinado, jogou a criança que despira no fundo do poço azul. Mariana gritou, entrando na água para salvar o filho (VASCONCELOS, 2010, p. 175).

Para Freyre (2006), os traços sádicos são tidos como algo até certo ponto comum na esfera escravocrata, como ressalta ao afirmar que "aquele mórbido deleite em ser mau com os inferiores e com os animais é bem nosso: é de todo o menino brasileiro atingido pela influência do sistema escravocrata" (FREYRE, 2006, p. 354). Assim, o que ocorre com Chica é uma influência desse sistema, pois ela somente apresentará traços de sadismo quando deixa de ser escrava e torna-se senhora da sociedade; ao ocupar esse papel, necessariamente começa a agir como os senhores brancos. Na época em questão, atitudes como a de Chica são vistas com normalidade, pois, considerando-se os escravos como seres inferiores, a classe mais elevada fazia o que bem queria com eles, não sendo punida por isso.

Por sua vez, a personagem Chica, de João Felício dos Santos, é descrita com muito erotismo, criando, na narrativa, uma esfera de teor sexual. Era uma mulher muito bonita e sedutora, como pode-se constatar nos seguintes trechos: "Xica era de matar um homem!", "Xica valia a pena" e "Xica, filha-da-puta mais traiçoeira do que leite posto a ferver em fogo alto, realçava o macio enxuto de suas curvas em sortidos gingos de inocentes cores" (SANTOS, 2007, p. 20). Seu lado sádico aparece pela primeira vez na descrição de uma relação sexual entre ela e o Sargento-mor.

É que, se a cura ou o restabelecimento das forças não se desse já longe do alcance das právidas mãos da mulata terrível, senão ainda debaixo dos mais ardentes tapas e dentadas cruentas, por todo o corpo, complementos exigidos para a satisfação da libido originalíssima, sua vítima havia de retornar fatalmente à inconsciência total, após os mais complexos e renovados orgasmos (SANTOS, 2007, p. 46).

Notamos, com o trecho anterior, traços da personalidade de Chica que a caracterizam sádica, pelo viés sexual, pois ela os cometia apenas durante as relações sexuais, como busca de provocar prazer nela e em seu parceiro. A esses atos de Chica não se podia escapar, como 
observamos a partir do uso do termo mulata terrível, que tem como objetivo referir-se a ela como uma mulata invencível, contra a qual não se pode lutar. O sadismo nessa esfera:

É a experiência de sensações sexuais prazerosas (incluindo o orgasmo) produzidas por atos de crueldade, punição corporal infligida a si mesmo ou testemunhada por outros, sejam eles animais ou seres humanos. Pode também consistir de um desejo inato de humilhar, machucar, ferir ou até mesmo destruir outros a fim de criar prazer sexual para si mesmo (KRAFFT-EBING, 1965, p. 53, apud PERACHI, 2014, p. 73).

Para Krafft-Ebing (1965, apud PERACHI, 2014), o sadismo é marcado por atos de crueldade e violência. Essas práticas têm, como finalidade, gerar prazer sexual no indivíduo que comete o ato. Portanto, a prática é considerada um tipo de perversão sexual, ou seja, uma psicopatia. Ademais, Sanchez (2007) enfatiza que consiste em uma classificação dos comportamentos sexuais desviantes em que o sadismo sexual é a busca do prazer por meio de atos em que a pulsão sexual advém do sofrimento, dor e humilhação do parceiro, que é o inverso do masoquismo.

No caso da personagem, nota-se essa pulsão sexual nas descrições de seus encontros sexuais; além da passagem com o Sargento-mor, há outra com o contratador de diamantes:

João Fernandes é que, não obstante o costumeiro exercício em cruentos diários, berrava, se defendendo com unhas e dentes, das carícias infernais da mulata que, repetidas ao infinito, sem tréguas, se faziam um cristão chegar aos paroxismos do céu, atiravam-no, também e ao mesmo tempo, aos piores suplícios infernais (SANTOS, 2007, p. 109).

Ademais, "Xica se atirou ao chão, agarrada a João Fernandes que ria-gemia-chorava-gritava-protestava-esperneava-sofria-gozava" (SANTOS, 2007, p. 132). Por esse trecho, notamos que seu parceiro sentia sofrimento com seus atos, mas, ao mesmo tempo, esses lhe provocavam prazer. Isso é reforçado pela seguinte construção incomum empregada pelo escritor "ria-gemia-chorava-gritava-protestava-esperneava-sofria-gozava", que expressa a ideia de tudo o que o contratador sentia, um misto de sensações paradoxais; faz-se uma opção pelo hífen, como se fosse construir uma palavra composta para designar o ato, que é único, porém repleto de variantes.

Deve-se dizer que, antes de tudo, a personagem Chica da Silva dos romances em questão são interpretações, criações ficcionais dos autores dentro de uma lógica criada para explicar lacunas sobre a história de Francisca, como, por exemplo, como um homem poderoso como João Fernandes se apaixona por uma escrava como ela.

No caso da Chica da Silva, do romance homônimo, o escritor recorre à imagem da mulher atraente com forte apetite sexual, tão difundida na época, pois, na visão do "branco", 
essa era uma possível explicação para o relacionamento entre duas pessoas de classes e raças tão distintas. Considerando o escritor tratar-se do sobrinho do renomado historiador Joaquim Felício dos Santos, supõe-se que tenha lido o trabalho de seu tio a respeito de Francisca e seguido a mesma linha ideológica que ele. Furtano (1998), em uma reportagem, afirma:

De acordo com Júnia, a ex-escrava tornou-se conhecida por sua crueldade e pelo grande apetite sexual graças ao livro Memórias do Distrito Diamantina, do século XIX, escrito por Joaquim Felício dos Santos. "A publicação faz de Chica a única negra a figurar em um registro histórico e o autor encontra no sexo e na perversidade os pretextos para uma escrava merecer tal destaque", diz (FURTANO, 1998, apud CORTELETI, 1998, on-line, grifo do autor).

Com o trecho da entrevista, podemos observar que o historiador relaciona a imagem de Francisca ao sexo e à perversidade. Torna-se possível, assim, estabelecer uma possível relação com a leitura feita sobre a personagem ficcional moldada por João Felício dos Santos, pois notam-se os dois itens na sua descrição: a perversidade aparece no seu lado sádico aparente em suas relações sexuais; e sua sensualidade está em todas as descrições na narrativa de sua aparência. Ressalta-se que, por se tratar de uma obra ficcional, inúmeros podem ter sido os contatos do escritor com obras textuais e extratextuais. Sobre como se processam esses contatos, Carvalhal (2006) afirma:

Dessa forma, é possível compreender que o "diálogo" entre os textos não é um processo tranquilo nem pacífico, pois, sendo os textos um espaço onde se inserem dialeticamente estruturas textuais e extratextuais, eles são um local de conflito, que cabe aos estudos comparados investigar numa perspectiva sistemática de leitura intertextual (CARVALHAL, 2006, p. 53).

Para a autora, é no texto que se apresenta o diálogo do escritor com as demais estruturas. Sendo a personagem parte fundamental da narrativa, por meio dela podem se apresentar as ideias do escritor, armazenadas e mixadas a partir do contato com as mais diversas fontes de conhecimento que se possa imaginar. Para Cândido (2011, p. 47), "as personagens não correspondem a pessoas vivas, mas nascem delas".

Assim, cada escritor se utiliza de artifícios próprios para impulsionar vida em seus personagens, como Brait (1985) explana:

Como um bruxo que vai dosando poções que se misturam num mágico caldeirão, o escritor recorre aos artifícios oferecidos por um código a fim de engendrar suas criaturas. Quer elas sejam tiradas de sua vivência real ou imaginária, dos sonhos, dos pesadelos ou das mesquinharias do cotidiano, a materialidade desses seres só pode ser atingida através de 
um jogo de linguagem que torne tangível a sua presença e sensíveis os seus movimentos. Se o texto é o produto final dessa espécie de bruxaria, ele é o único dado concreto capaz de fornecer os elementos utilizados pelo escritor para dar consistência à sua criação e estimular as reações do leitor. Nesse sentido, é possível detectar numa narrativa as formas encontradas pelo escritor para dar forma, para caracterizar as personagens, sejam elas encaradas como pura construção linguístico-literária ou espelho do ser humano (BRAIT, 1985, p. 52).

Segundo a citação acima, para Brait (1985), o que os escritores fazem é caracterizar suas personagens, por meio de suas intenções de impactar o leitor. Nesse sentido, a personagem de Vasconcelos (2010) traz a reflexão de como uma ex-escrava torna-se tão cruel após conquistar ascensão social, tornando-se manipuladora e dissimulada em prol de manter a paixão e as atenções do contratador sempre destinadas à pessoa dela. O sadismo de Chica, nesse romance, encontra-se amparado nos ciúmes doentios que ela sentia por João Fernandes; por conta disso, suas ações - por vezes cruéis - são desferidas contra aqueles que atravessam seu caminho e a ameaçam de alguma forma. Santos (2007) constrói Chica como uma mulher atraente e de "mil fazeres sexuais", de forma a explicar que, pelas habilidades sexuais, incluindo-se aí o sadismo como forma de prazer, João Fernandes fazia de tudo para mantê-la com ele.

Assim, cada escritor escolhe um sentido para dar forma em suas narrativas, pois, no texto, o escritor molda sua personagem conforme acha importante, para alcançar seus objetivos literários dentro da obra. Ademais, salienta-se que essas construções ficcionais, seja o personagem ou a narrativa em si, podem ser influenciadas pelas determinações culturais, sociais e os valores presentes no escritor. Exemplo disso são as distintas representações de Chica, pois, em Agripa Vasconcelos, percebemos a relação de superioridade e inferioridade existente entre senhores e escravos, e, na obra de João Felício dos Santos, notamos a existência da imagem estereotipada da mulher mulata sexualizada e racializada. Dessa maneira, percebemos que ambas as contruções apresentam ideologias dominantes presentes em si.

As narrativas analisadas possuem um narrador onisciente, que vê e sabe de tudo o que se passa com os personagens, no seu mais íntimo profundo. Para Brait (1985), a apresentação da personagem por um narrador que está fora da história é um recurso muito antigo e muito eficaz, dependendo da habilidade do escritor que o maneja. Num certo sentido, é um artifício primeiro, uma manifestação quase espontânea da tentativa de criar uma história que deve ganhar a credibilidade do leitor.

Por meio dos recursos textuais e da utilização do recurso do narrador onisciente é que ambos os escritores conseguem construir suas personagens como sádicas, pois essa característica faz parte do íntimo dos personagens. Não havendo um narrador oniscente, não poderia haver essas construções, em se tratando de algo estritamente ligado ao pessoal das personagens. É pela narração que ocorre a verossimilhança dos dados apresentados na narrativa. 
Em vista disso, temos o acesso, promovido pela ficção, ao encontros sexuais entre Chica e João Fernandes, com seus mais sórdidos detalhes, como no seguinte trecho: "rolavam na maior prosmicuidade pelos tapetes, já manchados, pelas almofadas já úmidas, e até pelo chão puro, já pegajoso em suspeitos líquidos nas tábuas enormes de jacarandá” (SANTOS, 2007, p. 109). Na obra de Vasconcelos (2010), por meio do narrador onisciente, temos contato com os crimes de Chica, pois há detalhes que só ela poderia saber e perscrutar, mas que o narrador desnuda aos olhos do leitor.

Portanto, o enfoque do narrador será nos momentos sádicos das personagens, como forma de reafirmar essa caracterização delas na narrativa. Como Brait (1985, p. 56) ressalta, "o narrador em terceira pessoa simula um registro contínuo, focalizando a personagem nos momentos precisos que interessam ao andamento da história e à materialização dos seres que a vivem". Salienta-se que seus recursos textuais são de grande valia nas narrativas, no processo de construção e veracidade dos personagens.

\section{Conclusão}

As narrativas de Agripa Vasconcelos e de João Felício dos Santos têm, como base para suas criações, o momento histórico das Minas mineradora e a pessoa de Francisca da Silva de Oliveira. É importante salientar que, mesmo tendo a mesma base histórica, seus percursos ficcionais diferem-se bastante no que diz respeito a quem foi Chica, pois cada autor apresenta diferentes possíveis respostas para as lacunas deixadas pela historiografia acerca da senhora Francisca. Os dois escritores trabalham na construção dela como sádica, mas se valem de interpretações e de olhares diferentes a respeito do significado que atribuem ao vocábulo.

Os recursos textuais e de narração evidenciam e reforçam como cada um dos escritores objetivou constituir sua personagem à sua maneira. Considerando que Vasconcelos (2010) escreveu primeiro, sugerem-se traços de proximidade entre as obras, pois, por meio da criação de um escritor, inúmeras podem ser as influências visíveis que ele pode causar a outros, de forma intencional ou não.

As obras dos dois escritores são de suma importância para os estudos sobre o gênero romance histórico. Apesar de diferirem em suas construções, trabalham com o mesmo elemento. Sendo assim, importa entendermos como um mesmo elemento pode possuir diferentes interpretações. Isso, de alguma maneira, fornece o tom principal de cada narrativa, revelando detalhes que a história oficial não consegue fornecer, devido à preocupação em relatar uma verdade - o mesmo já não se pode dizer da ficção.

Os escritores utilizam-se de artifícios e estratégias próprias com a intenção de conquistar a credibilidade do leitor, o que pode gerar a impressão de que a obra pode ser entendida como uma biografia. Dessa forma, alguns dados ficcionais podem ser confundidos com dados verídicos, que acabam resultando na disseminação de uma imagem estereotipada da pessoa 
histórica de Chica da Silva, levando a interpretá-la como uma mulher que, de fato, correspondia às características dadas a ela pelos romances. Entretanto, há que se fazer separação, sabendo discernir a ficção daquilo que é fato histórico. Enfim, considerando que ambas as narrativas enquadram-se no gênero romance histórico, possuem dados históricos e ficcionais em sua composição. Nenhuma delas, porém, tem como propósito retratar a real pessoa de Francisca da Silva de Oliveira, mas apresentar uma possível leitura de como foi sua vivência no século XVIII, com as cores, os nós e os sabores que a literatura é capaz de nos fornecer.

\section{REFERÊNCIAS}

BAKHTIN, Mikhail. Questões de literatura e de estética (A teoria do romance). Tradução de Aurora F. Bernardini et al. 2. ed. São Paulo: Editora Unesp; Hucitec, 1990.

BRAIT, Beth. A Personagem. 3. ed. São Paulo: Ática, 1985.

CÂNDIDO, Antonio. A personagem do romance. In: CÂNDIDO, Antonio et al. A personagem da ficção. 12. ed. São Paulo: Perspectiva, 2011.

CARVALHAL, Tânia Franco. Literatura Comparada. 4. ed. São Paulo: Ática, 2006.

CORTELETI, Marco Antônio. Pesquisa contesta mito de Chica da Silva. 1998. Disponível em: https://www.ufmg.br/boletim/boli207/pag4.html. Acesso em: 12 jan. 2020.

DIEGUES, Cacá. Relações Literárias: João Felício dos Santos. OEstado de Minas, Belo Horizonte, 3 mar. 2007. Disponível em: http://www.tirodeletra.com.br/relacoes/JoaoFeliciodosSantos. htm. Acesso em: 15 jan. 2020.

ESTEVES, Antonio R. O romance histórico brasileiro contemporâneo. São Paulo: UNESP, 2010.

FERREIRA, Aurélio Buarque de Holanda. Dicionário da língua portuguesa. 5. ed. Curitiba: Positivo, 2010. 2222 p.

FREYRE, Gilberto. Características gerais da colonização portuguesa no Brasil: formação de uma sociedade agrária, escravocrata e híbrida. In: Casa-grande \& senzala: formação da família brasileira sob o regime da economia patriarcal. 51. ed. rev. São Paulo: Global, 2006.

FURTANO, Júnia Ferreira. Chica da Silva e o contratador dos diamantes. 1. ed. São Paulo: Companhia das Letras, 2003.

LUKÁCS, Georg. 0 romance histórico. São Paulo: Boitempo, 2011.

MANCINI, Mara Sylvia Vasconcellos; MENON, Maurício Cesar Menon; SILVA, Sandro Adriano. Agripa Vasconcelos: do poeta ao romancista das gerais. São Paulo: Pedro \& João, 2018.

MIRANDA, Ana. Xica da Silva: a Cinderela Negra. 2. ed. Rio de Janeiro: Record, 2017. 
PERACHI, Camila Taiara et al. Construções freudianas acerca do sadismo e do masoquismo: uma ruptura com a tradição médica. Fisioterapia em Movimento, Curitiba, v. 32, n. 79, p. 7183, mar. 2014.

SANCHEZ, G. A orgia de Marquês de Sade: obra do homem que originou o termo. Guia do Estudante. 1 maio 2007. Disponível em: http://origin.guiadoestudante.abril.com.br/aventurashistoria/orgia-marques-sade435297.shtml. Acesso em: 11 set. 2017.

SANTOS, João Felício dos. Xica da Silva. 3. ed. Rio de Janeiro: José Olympio, 2007.

SANTOS, Elizete de Souza de Oliveira; BUCHER, Bernadeth. Transtorno parafiliaco: Sadismo e Masoquismo. Conexão Eletrônica, Três Lagoas, v. 12, n. 1, p. 726-734, jan. 2018.

SOETHE, Paulo Astor. Literatura Comparada. Curitiba: IESDE Brasil S.A., 2009.

VASCONCELOS, Agripa. Chica que Manda. 1. ed. Belo Horizonte: Editora Itatiaia, 2010.

WEINHARDT, Marilene. Considerações sobre o romance histórico. Letras, Curitiba, v. 43, n. 1, p. 49-59, jan. 1994.

Recebido para publicação em: 15 maio 2020. Aceito para publicação em: 15 set. 2020. 